\title{
PROJETOS DE LETRAMENTO NA ESCOLA: EXPERIÊNCIAS NO ESTÁGIO CURRICULAR SUPERVISIONADO DE LÍNGUA PORTUGUESA E LITERATURAS
}

\author{
Projects of Literacy in School: Experiences in the Supervised Curricular \\ Internship of Portuguese Language and Literatures
}

\author{
Jakeline SEMECHECHEM \\ Universidade Federal do Recôncavo da Bahia \\ jakeline@ufrb.edu.br \\ https://orcid.org/0000-0002-4682-0587
}

\begin{abstract}
RESUMO: Este relato de experiência tem como objetivo apresentar um trabalho desenvolvido no Estágio Curricular Supervisionado de Língua Portuguesa e Literaturas, no curso de Letras Português/Inglês, de uma Universidade Pública no Norte do Paraná. Considerando as discussões sobre as modalidades de Estágio Supervisionado e a relevância de projetos nessa etapa (PIMENTA; LIMA, 2018), foi desenvolvido um projeto de intervenção no estágio visando a realização de oficinas em escolas públicas. As bases teórico-metodológicas que fundamentaram o trabalho foram os pressupostos da pedagogia de projetos de letramento (KLEIMAN, 2000; OLIVEIRA, 2008; SOUZA; OLIVEIRA, 2017) e de sequência didática de gêneros (DOLZ; NOVERRAZ; SCHNEUWLY, 2004, BARROS, 2012; GUIMARÃES; KERSCH, 2015; BARROS; STORTO, 2017; STRIQUER; OLIVEIRA, 2017; BARROS; STRIQUER; STORTO, 2018). Com base nos resultados desta experiência, foi possível verificar a contribuição do projeto de intervenção no estágio tanto para formação docente dos acadêmicos de Letras quanto para as escolas, campo social de estágio.
\end{abstract}

PALAVRAS-CHAVE: Estágio Curricular Supervisionado de Língua Portuguesa; Formação Docente; Projeto de Intervenção; Projetos de Letramento.

\begin{abstract}
This experience report aims to present a project developed during the Supervised Curricular Internship of Portuguese Language and Literature, in the Portuguese/English undergraduate course at a Public University in the North of Paraná. Thus, considering the discussions about the modalities of Supervised Curricular Internship and the relevance of projects at this stage (PIMENTA; LIMA, 2018), we developed an intervention with workshops in public schools. The theoretical-methodological focused on the pedagogy of literacy projects (KLEIMAN, 2000; OLIVEIRA, 2008; SOUZA; OLIVEIRA, 2017) and in the didactic sequence of genres (DOLZ; NOVERRAZ; SCHNEUWLY, 2004; BARROS, 2012; GUIMARÃES; KERSCH,
\end{abstract}


2015; BARROS; STORTO, 2017; STRIQUER; OLIVEIRA, 2017; BARROS; STRIQUER; STORTO, 2018). Based on the results of this experience, it was possible to verify the contribution of the project of intervention in internships for the development of academics and for the schools, social field of supervised internships.

KEYWORDS: Supervised Curricular Internship of Portuguese Language and Literatures; Teacher Education; Project of Intervention; Literacy Projects.

\section{INTRODUÇÃO}

Pimenta e Lima (2018) defendem o Estágio Curricular Supervisionado dos cursos de formação de professores como um espaço para a produção de conhecimento sobre a profissão docente, o que envolve teoria, prática, reflexão, produção de conhecimento sobre o professor e sua profissão, bem como sobre o processo educativo. Conforme as autoras, o estágio se constitui em uma atividade teórica de conhecimento e aproximação da realidade educacional como prática social ${ }^{1}$ e instrumentalizadora da práxis do futuro professor.

Nesse sentido, é preciso considerar que para a compreensão do Estágio Curricular Supervisionado como um campo de conhecimento, é necessário atribuir-lhe um estatuto epistemológico que supere sua tradicional redução à atividade prática instrumental de aplicação de técnicas, rituais e normas aprendidas na teoria ou de uma prática como imitação de modelos (ALMEIDA; PIMENTA, 2014).

Entretanto, tal concepção exige um planejamento que pode envolver planos e projetos em consonância com a proposta curricular do curso (PIMENTA; LIMA, 2018) em articulação com as instituições de Educação Básica, uma vez que o estágio se produz na interação dos cursos com o campo social no qual se desenvolvem as práticas educativas (ALMEIDA; PIMENTA, 2014), ou seja, com as escolas.

Dornelles (2012), portanto, destaca que necessitamos de um tipo de relação entre a universidade e as escolas em que o estágio contribuía para uma ação reflexiva, crítica e colaborativa em meio a todos, deslocando estagiários, professores regentes e formadores de seus papéis tradicionais, muitas vezes restritos ao cumprimento burocrático.

\footnotetext{
${ }^{1}$ Cabe ressaltar que conhecimento da educação como prática social, segundo Pimenta e Lima (2018), deve envolver o estudo, a análise, a problematização, a reflexão e a proposição de soluções às situações de ensinar e aprender.
} 
Nessa perspectiva, os projetos podem ser profícuos, uma vez que são possibilidades metodológicas para o cumprimento das finalidades do estágio (PIMENTA; LIMA, 2018). Para as autoras, os projetos podem ser: de pesquisa, no caso de estágios planejados com pesquisa e como pesquisa; e de intervenção, que podem responder às demandas da escola, nutrindo-se delas para a elaboração de propostas.

Os projetos de intervenção, segundo Pimenta e Lima (2018), têm a intencionalidade expressa na própria designação, pois eles se destinam à ação e à intervenção nas práticas pedagógicas. Esses tipos de projetos no estágio possibilitam que:

os estagiários vivenciem um processo em todas as suas etapas de diagnóstico, planejamento, execução e avaliação, em um espaço de tempo com começo, meio e fim, e lhe permite ser aprendiz e autor simultaneamente, enquanto aprende a organizar e a gerir o que é necessário e possível em determinado tempo (PIMENTA; LIMA, 2018, s.p. $\mathbf{p}^{2}$.

Além disso, eles são caminhos teórico-metodológicos de mão dupla para a formação e para a criação de possibilidades de melhoria das escolas, pois podem envolver dimensões pedagógicas: currículo, práticas, avaliação, metodologias de ensinoaprendizagem, disciplinas específicas, reforço escolar etc., bem como as dimensões organizacional, profissional e social (PIMENTA; LIMA, 2018).

Neste texto, pretendo relatar uma experiência que tive como orientadora de Estágio Curricular Supervisionado de Língua Portuguesa e Literaturas do Curso de Letras Português/Inglês, em uma Universidade Pública no Norte do Paraná, no período de 2017 e 2018. A experiência consiste na realização de parte do estágio por meio de projeto de intervenção ${ }^{3}$, no qual os acadêmicos estagiários ministraram oficinas em escolas públicas da rede estadual de ensino, tendo como pressuposto teórico-metodológico central o desenvolvimento de projetos de letramento, que consistem em "um conjunto de atividades que se origina de um interesse real na vida dos alunos e cuja realização envolve o uso da escrita, isto é, a leitura e a escrita de textos que, de fato, circulam na sociedade e a

\footnotetext{
${ }^{2}$ Foi utilizada a 1. ed. em e-book de Pimenta e Lima (2018). O e-book não apresenta número de páginas, somente posições para localização. Por isso, as citações diretas retiradas do e-book não terão as páginas indicadas neste relato de experiência.

${ }^{3}$ Os projetos de intervenção de estágio estavam inseridos em projetos de extensão (que serão relatados na próxima seção). Os projetos de extensão são entendidos como o planejamento de ações visando a articulação entre a universidade e a sociedade, ou seja, entre a universidade e a comunidade externa.
} 
produção de textos que serão realmente lidos [...]" (KLEIMAN 2000, p. 238).

Para relatar essa experiência, primeiramente, contextualizo os projetos de intervenção, para, então, apresentar por que, como orientadora de Estágio Supervisionado de Língua Portuguesa e Literaturas, optei pela proposta de intervenções pautadas na pedagogia dos projetos de letramento. Em seguida, apresento os pressupostos teóricometodológicos que adotei para subsidiá-los nas escolas e alguns dos seus resultados.

\section{PROJETOS E O ESTÁGIO CURRICULAR SUPERVISIONADO NO CURSO DE LETRAS: UMA EXPERIÊNCIA}

No curso de Letras Português/Inglês, da Universidade Pública onde foi desenvolvido o trabalho apresentado neste relato, nos Estágios Curriculares Supervisionados de Língua Portuguesa e de Língua Inglesa, no período de 2017 e 2018, havia ${ }^{4}$, no Projeto Pedagógico do Curso (PPC) e nos manuais de estágio do curso, previsão de realização das seguintes atividades: estudos teóricos e práticos, análise de material didático, preparação de planos de aulas e de materiais didáticos, levantamento do contexto educacional, observação e regência.

A regência era prevista sob duas modalidades: a obrigatória e a complementar, assim contemplando aulas regulares nos Anos Finais do Ensino Fundamental e Ensino Médio e projetos de ensino em contraturno, com oficinas nas escolas de Educação Básica ou outras instituições (MANUAL DE ESTÁGIO SUPERVISIONADO OBRIGATÓRIO DO CURSO DE LETRAS PORTUGUÊS/INGLÊS, 2018). A regência complementar podia ser realizada em articulação com ações de extensão.

De acordo com o projeto pedagógico do curso "as regências serão realizadas na rede básica de ensino e também poderão ser desenvolvidas a partir de Projeto de Extensão" (PROJETO PEDAGÓGICO DO CURSO DE LETRAS PORTUGUÊS/ INGLÊS, 2012, p. 31). Desse modo, eram propostos projetos de extensão para abarcar ações de estágio supervisionado obrigatório, especialmente atividades de regência na modalidade complementar.

\footnotetext{
${ }^{4}$ Aqui coloco que "havia", e não que "há", pois houve reformulação do PPC em 2019, período em que mudei para outra instituição.
} 
No referido curso, em 2017, tínhamos um projeto de extensão para abarcar atividades vinculadas ao Estágio, o "Leitura e produção textual: atuação comunitária", que visava ampliar a oportunidade de inserção dos licenciandos no ambiente escolar para promover a articulação entre as Licenciaturas e as instituições de ensino da Educação Básica, bem como expandir as possibilidades de conexão entre teoria e prática dos futuros professores. Também visava contribuir para o trabalho com a leitura e a produção escrita na Educação Básica (VALENTE, 2017).

Então, tendo em vista esse projeto de extensão, as demandas de Estágio Curricular Supervisionado de Língua Portuguesa e Literaturas I, minha formação e produção acadêmica voltadas para os estudos de letramento em uma perspectiva sociocultural, como orientadora de estágio, iniciei um projeto de intervenção com ações de ensino (oficinas de leitura e produção textual) voltadas para alunos dos Anos Finais do Ensino Fundamental, para ser desenvolvida pelos estagiários.

Para fundamentar teórico-metodologicamente essas ações, pautei-me na pedagogia dos projetos de letramento e também na sequência didática de gêneros, do Interacionismo Sociodiscursivo (ISD). Esta última com algumas modificações sobre as quais comento na seção sobre pressupostos teórico-metodológicos, no trabalho com sequência didática do Programa Escrevendo o Futuro - Olimpíada de Língua Portuguesa. Com esse enfoque, os estagiários realizaram oficinas em duas escolas no ano de 2017, por meio do trabalho com projetos de letramento.

Em 2018, partindo das ações de intervenção desenvolvidas em 2017, propus alterações no projeto, inserindo-o em um novo projeto de extensão do curso, denominado "Práticas de leitura e produção textual: educação básica e formação inicial em foco", que tinha os seguintes objetivos:

[...] oferecer cursos de curta duração para a comunidade externa da [universidade], sobretudo alunos da Educação Básica. Esses cursos visam de um lado preparar os alunos da Educação Básica para o PROCESSO SELETIVO (VESTIBULAR) da [universidade], bem como oferecer oficinas focadas no processo de letramento em Língua Portuguesa e, de outro, potencializar a formação inicial dos graduandos do curso de Letras Português-Inglês [...] (BRANDILEONE, 2018, p. 1).

Essa proposta possibilitou espaço para o desenvolvimento de várias ações 
vinculadas ao Estágio Curricular Supervisionado no curso, cada uma com seus objetivos e pressupostos teórico-metodológicos particulares. Assim, dentro desse projeto de extensão foram desenvolvidas diferentes ações ${ }^{5}$ com a atuação de outros professores orientadores de estágio de língua portuguesa e literatura e de língua inglesa. No entanto, neste texto trato apenas das ações planejadas e orientadas por mim dentro do meu projeto de intervenção, que, fez parte do referido projeto de extensão.

Com base na experiência com o projeto de intervenção em 2017, considerei necessárias reformulações no projeto de intervenção de 2018: o modo de escolha da prática social para o projeto de letramento, inserção de questões da Base Nacional Comum Curricular (BNCC) no planejamento, bem como de contribuições de uma proposta denominada projeto didático de gêneros (PDG), com um enfoque maior no trabalho com leitura e alterações na organização da sequência didática (questões que retomarei posteriormente no texto). Assim, seguindo esses pressupostos, os estagiários realizaram oficinas em três escolas.

A seguir, apresento por que, como orientadora de Estágio Curricular Supervisionado de Língua Portuguesa e Literaturas, optei por planejaras ações do projeto de intervenção vinculado pautadas na pedagogia dos projetos de letramento.

\section{POR QUE A PROPOSTA DE OFICINAS PARA ALUNOS DOS ANOS FINAIS DO ENSINO FUNDAMENTAL NA PERSPECTIVA DOS PROJETOS DE LETRA- MENTO?}

As orientações dos Parâmetros Curriculares Nacionais - Ensino Fundamental (PCN) (BRASIL, 1998), das Diretrizes Curriculares do Estado do Paraná (PARANÁ, 2008) e, mais recentemente, da Base Nacional Comum Curricular - BNCC (BRASIL, 2017), são de que o ensino de Língua Portuguesa seja pautado em textos e gêneros textuais nos Anos Finais do Ensino Fundamental. Sobretudo como é destacado na Base Nacional Comum Curricular:

Ao componente Língua Portuguesa cabe, então, proporcionar aos estudantes experiências que contribuam para a ampliação dos

\footnotetext{
${ }^{5}$ Outras ações estão voltadas para cursos preparatórios para o vestibular da Universidade: literatura no vestibular da instituição, a produção textual do artigo de opinião e inglês instrumental: curso preparatório para o vestibular.
} 
letramentos, de forma a possibilitar a participação significativa e crítica nas diversas práticas sociais permeadas/constituídas pela oralidade, pela escrita e por outras linguagens (BRASIL, 2017, p. 65).

Embora seja possível identificar que esses documentos apresentam diferentes conceitos de letramento, é indiscutível que eles reconhecem sua importância. Segundo Soares (2010), diferenças na conceituação de letramento resultam em diferentes implicações para as práticas educacionais. Nesse viés, entendo letramento em uma perspectiva sociocultural, que o considera como plural, ideológico, para além de habilidades neutras de leitura e escrita, especificamente como práticas sociais de leitura e de escrita (STREET, 2003, 2010).

Reconheço também que trabalhar com o letramento no ensino de Língua Portuguesa significa criar oportunidades para que os alunos possam desenvolver condições para participar das diversas práticas letradas (que envolvem a leitura, a escrita e outras linguagens) na sociedade contemporânea e consigam exercer os seus direitos e sua cidadania. Em suma, atuar no mundo, nas diferentes esferas sociais, desde a cotidiana às públicas e mais complexas.

Nessa perspectiva, a fim de aumentar as condições que possibilitam a participação dos alunos de escolas públicas, de um município no Norte do Paraná, nas diferentes práticas letradas na sociedade contemporânea, nos diversos campos de atuação em que as práticas de linguagem se realizam "Campo artístico-literário, Campo das práticas de estudo e pesquisa, Campo jornalístico/midiático e Campo de atuação na vida pública" (BRASIL, 2017, p. 82), foram propostos os projetos de intervenção no estágio. Esses projetos tinham como objetivo realizar oficinas para o trabalho com práticas de linguagem de língua portuguesa por meio de projetos de letramento.

As oficinas propostas tiveram como base central a pedagogia de projetos de letramento, que visa atender às demandas e necessidades das escolas e do alunado em termos do desenvolvimento de condições para realizar/participar de diferentes práticas letradas, uma vez que, como ressalta Oliveira (2010), tendo como ponto de partida a prática social, esses projetos pretendem atender a necessidades sociais e demandas comunicativas específicas de um determinado grupo.

Em síntese, o projeto de intervenção ancorado nos pressupostos teórico- 
metodológicos de projetos de letramento, visava desenvolver oficinas nas escolas, em contraturno, com o seguinte objetivo geral: ampliar as oportunidades dos alunos das escolas públicas desenvolverem condições para participar de práticas letradas na sociedade contemporânea.

As oficinas ofertadas para os alunos das escolas públicas justificam-se, em primeiro lugar, pelo fato de a escola, como uma das mais importantes agências de letramento (KLEIMAN, 2007) ou como "uma das principais instâncias sociais responsáveis pelo acesso às diversas formas de letramento e pelo desenvolvimento das capacidades de leitura e de escrita dos alunos" (CORDEIRO; BARROS; GONÇALVES, 2017 , p. 15) ser assim uma das principais responsáveis por possibilitar que os alunos tenham condições de participar de práticas letradas na sociedade contemporânea, especialmente nas esferas públicas.

Além disso, conforme Borges da Silva (2013, p. 283), "a escola é um espaço que, nos últimos anos, vem tentando se redesenhar, em função, principalmente, das transformações sociais do mundo contemporâneo, que requer das pessoas complexas habilidades em leitura e escrita". Desse modo, por meio de projetos de letramento as oficinas podem contribuir com esse papel da escola. Servem para somar na função da escola como agência de letramento, tendo os acadêmicos estagiários como seus agentes.

Justifica-se a escolha pela realização das oficinas nas escolas e pelo viés de projetos de letramento porque eles

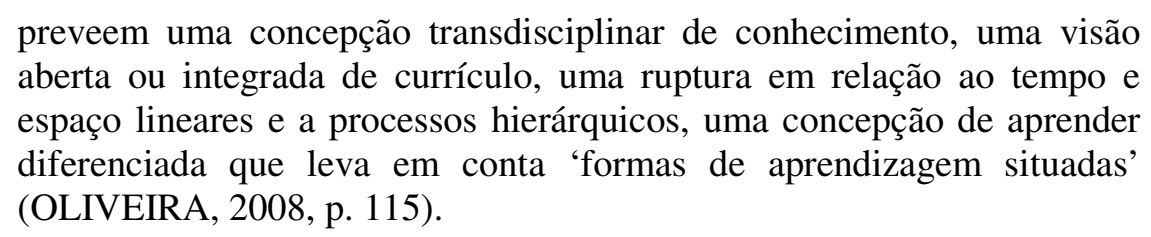

Dessa maneira, esses outros espaços e tempos de aprendizagem podem ser diferentes, desenvolvidos de modo mais flexível em relação ao currículo e de modo situado, ou seja, inseparáveis das práticas sociais, pois para Lave e Wenger (1991, p. 31), aprendizagem situada pode ser compreendida "como algo contínuo de nossa participação no mundo [...] um aspecto integral e inseparável da prática social”.

Também justifica-se o desenvolvimento das oficinas tendo como pressuposto 
teórico-metodológico os projetos de letramento, pois por meio deles é possível "atentar para as necessidades e interesses dos alunos, em especial para o contexto em que estão inseridos" (SOUZA; OLIVEIRA, 2017, p. 142), contribuindo para o que Street (2003) salienta como necessário, a implementação de programas mais sensíveis culturalmente e relacionados ao que as pessoas realmente precisam.

O desenvolvimento das oficinas nas escolas públicas, em horário contraturno, justifica-se também porque elas contribuem com a "[...] ampliação de tempos, espaços e oportunidades de aprendizagem que visam ampliar a formação do aluno [...]", conforme disposto na instrução n. ${ }^{\circ}$ 007/2012 SEED/SUED, sobre o Programa de Atividades Complementares Curriculares em Contraturno, nas instituições de ensino da rede estadual.

Por fim, as oficinas ministradas por acadêmicos de Estágio Curricular Supervisionado de Língua Portuguesa e Literaturas I contribuem tanto para a formação dos estudantes da escola quanto para a formação docente inicial dos acadêmicos estagiários.

\section{PRESSUPOSTOS TEÓRICO-METODOLÓGICOS: PROJETOS DE LETRA- MENTO E SEQUÊNCIA DIDÁTICA DE GÊNEROS}

Os projetos de letramento são um eixo estruturador das atividades em sala de aula que permitem ressignificar temas e conteúdos no contexto e não são substitutos dos eixos temáticos ou dos eixos conteudísticos relevantes no trabalho escolar (KLEIMAN, 2007). Isso porque o eixo passa a ser o letramento como objetivo da ação pedagógica, o movimento será da prática social para o conteúdo, nunca o contrário (KLEIMAN, 2007).

Consoante Kleiman (2007), nos projetos de letramento, diferentemente das atividades analíticas em que se escreve e se lê para aprender a escrever e a ler, o foco na atividade em questão deve estar na prática letrada, em vez de estar no gênero ou texto a ser produzido, deve estar na prática social que se realiza por meio da linguagem.

Entretanto, mesmo o gênero textual não sendo o ponto de partida e o objeto central de ensino, o projeto também se pauta nele, uma vez que, conforme pontua Oliveira (2010, p. 340), o "ensinar e o aprender nos projetos de letramento se efetivam por meio do trabalho com os gêneros, entendidos como instrumentos mediadores da ação humana no mundo". Precisa-se considerar que os gêneros textuais intermedeiam e integram as 
práticas às atividades de linguagem e são referências fundamentais para sua construção (ROJO, 2006). Dessa maneira, não há como tratar de práticas sociais que envolvem o uso da linguagem sem considerá-los.

Nessa perspectiva, ainda em relação aos gêneros textuais, Oliveira (2010, p. 342) aponta "[...] os projetos de letramento como práticas que contextualizam a leitura e a escrita, possibilitando abordar os gêneros não como um 'fim', mas como um 'meio'. Corresponde, noutros termos, a ensinar com os gêneros e não sobre os gêneros [...]".

Assim, podemos sintetizar a proposta de projetos de letramento do seguinte modo:

Figura 1: Projetos de letramento

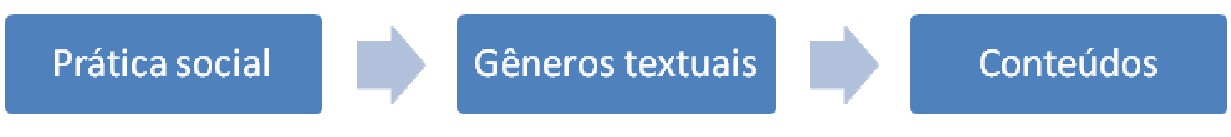

Fonte: A autora.

Souza e Oliveira (2017, p. 142), por sua vez, rediscutem projeto de letramento e salientam que "está imbricado às noções de gênero, eventos e práticas de letramento, já que, no trabalho com esse dispositivo didático, existe a preocupação com a vivência efetiva de gêneros em eventos respaldados por práticas de letramentos que ocorrem no meio social". Desse modo, também são importantes os eventos e práticas de letramento, conceitos propostos pelos estudos na perspectiva sociocultural de letramento.

\footnotetext{
Shirley Brice Heath descreveu um 'evento de letramento' como qualquer ocasião em que um texto escrito faça parte da natureza das interações dos participantes e de seus processos interpretativos. [...] as práticas de letramento referem-se a esse conceito cultural mais amplo das formas específicas de pensar e de fazer a leitura e a escrita dentro dos contextos culturais (STREET, 2003, p. 7-8).
}

A seguir, apresento uma síntese dos projetos de letramento considerando os conceitos da perspectiva sociocultural de letramento, conforme discutem Kleiman (2000) e Souza e Oliveira (2017). 
Figura 2: Projetos de letramento

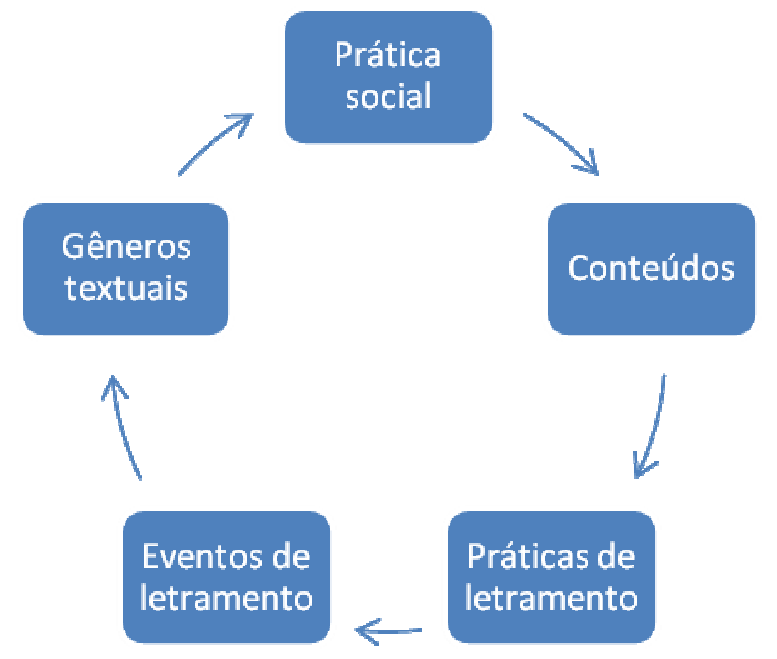

Fonte: A autora.

Nesse viés, ao trabalhar com projetos de letramento, o professor ou outro agente adotará a prática social como princípio organizador do ensino e, por isso, enfrentará a complexa tarefa de determinar quais são essas práticas significativas e os textos necessários para realizá-las. Porém, essa tarefa é complexa porque requer partir "[...] da bagagem cultural diversificada dos alunos que, antes já são participantes de atividades corriqueiras de grupos que, central ou perifericamente, com diferentes graus e modos de participação" (KLEIMAN, 2007, p. 9).

Além de partir das práticas letradas das quais os alunos já participam ou considerálas, é necessário atentar-se para as necessidades e interesses dos estudantes, em especial para o contexto em que estão inseridos (SOUZA; OLIVEIRA, 2017). Com isso são consideradas as reivindicações locais, participando de suas demandas, em consonância com as palavras de Street (2010, p. 49): "deixem-nos ajudar naquilo em que vocês querem ajuda".

No ensino pautado em projetos de letramento não há necessidade de se trabalhar conteúdos programáticos predefinidos, pois o ponto de partida para seu planejamento deve ser a prática social, a demanda de situações específicas. Todavia, isso não significa que os projetos não possam estar articulados com o currículo, uma vez que podem ser integrados ou não a ele (OLIVEIRA, 2008).

Para a realização do projeto de intervenção do estágio que propõe o 
desenvolvimento de projetos de letramento nas escolas foram planejadas oficinas voltadas para práticas de linguagem selecionadas a partir do conhecimento adquirido sobre as condições socioeconômica, cultural, política e ideológica da comunidade e com base nos interesses e necessidades dos alunos e professores.

Os conjuntos de atividades das oficinas foram planejados também com base na proposta teórico-metodológica da sequência didática de gêneros, conforme estudiosos alinhados ao Interacionismo Sociodiscursivo (BARROS, 2012; BARROS; BARDIN, 2012; BARROS; STORTO, 2017; BARROS; MAFRA; STORTO, 2017; STRIQUER; OLIVEIRA, 2017; CORDEIRO; BARROS; GONÇALVES, 2017; BARROS; STRIQUER; STORTO, 2018).

Conforme Dolz, Noverraz e Schneuwly (2004, p. 82), “a sequência didática é um conjunto de atividades escolares organizadas, de maneira sistemática, em torno de um gênero oral ou escrito". São a primeira relação entre um projeto de apropriação de uma prática de linguagem e os instrumentos que a facilitam, pois elas buscam confrontar os alunos com os gêneros textuais para lhes dar a possibilidade de reconstruí-los e deles se apropriarem (DOLZ; SCHNEUWLY, 2004).

A sequência didática " [....] tem como objetivo, portanto, a partir de um projeto de ensino, fazer com que o aluno se aproprie de uma prática linguageira, essa sempre configurada em um gênero de texto" (BARROS; BARDINI, 2012, p. 89). E possui quatro etapas: apresentação da situação inicial, produção inicial, módulos e produção final (DOLZ; NOVERRAZ; SCHNEUWLY, 2004). Das quais considerei todas, porém com adaptações.

$\mathrm{Na}$ “Apresentação da situação", que denominamos de primeira oficina, apresentamos $^{6}$ a prática de linguagem e discutimos sobre o projeto comunicativo a ser desenvolvido, conforme acordado previamente com os participantes. Fizemos a sensibilização ao gênero e discutimos as condições de produção. Também propomos uma primeira produção escrita para fazer uma avaliação diagnóstica dos alunos.

$\mathrm{Na}$ sequência, no lugar da primeira produção do gênero, propomos módulos/ oficinas para trabalhar com o gênero textual ${ }^{7}$ e com práticas de leitura, uma vez que são as

\footnotetext{
${ }^{6} \mathrm{O}$ uso da terceira pessoal do plural se dá nos momentos que me refiro a ações realizadas pelos acadêmicos estagiários e por mim.

${ }^{7}$ Em concordância com Striquer e Oliveira (2017), que ressaltam a importância de o aluno conhecer as
} 
“[...] atividades de leitura que encaminham a produção textual” (GUIMARÃES; KERSCH, 2015, p. 14). Nessas atividades trabalhamos condições de produção, aspectos linguístico-discursivos e enunciativos do gênero.

As adaptações não estão somente relacionadas à sequencialidade das etapas, mas seguindo o que propõem Guimarães e Kersch (2015, p. 14), sob essa perspectiva, procuramos, no desenvolvimento das sequências,

[...] colocar a produção de leitura lado a lado com a produção textual, entendendo-as dentro da perspectiva dos estudos de letramento: como práticas sociais que emergem de outras práticas da comunidade em que os alunos estão inseridos (BARTON; HAMILTON 1998; KLEIMAN 1995 [2008]; OLIVEIRA, 2010). Diferentemente do proposto pelo grupo de Genebra, procuramos atribuir ao processo de leitura a mesma importância do processo de produção textual, dando, porém, um detalhamento semelhante. (GUIMARÃES; KERSCH, 2015, p. 14).

Após as primeiras oficinas voltadas para práticas de leitura, reconhecimento do contexto de produção, do gênero a ser produzido, das dimensões linguístico-discursivas e enunciativas ( 2 ou 3 oficinas a depender do contexto), passamos para a etapa da "produção da primeira versão". Depois, planejamos e desenvolvemos outras oficinas para trabalhar com as capacidades de linguagem, bem como com as dificuldades e potencialidades identificadas na primeira produção do gênero (cerca de 3 oficinas).

Realizamos, então, a última oficina com estratégias de avaliação, autoavaliação e reescrita para a produção final. Por fim, inserimos mais uma etapa, posterior à da produção final, a circulação; assim, “[...] além de dominar o gênero, o aluno vai fazê-lo circular, vai devolvê-lo ao seu lugar de origem, fazendo-o cumprir seu papel, compreendendo que escrevemos para agir no mundo (dentro e fora da escola) (GUIMARÃES; KERSCH, 2015, p. 11).

Portanto, para o desenvolvimento dos projetos de letramento consideramos a proposta teórico-metodológica das sequências didáticas de gênero, conforme proposta por

especificidades do gênero (especificidades contextuais, linguístico-discursivas e enunciativas) na apresentação da situação inicial, para então produzi-lo. No entanto, no caso dos projetos de letramento, usamos mais de uma oficina para trabalhar com as especificidades contextuais, linguístico-discursivas e enunciativas do gênero, para então, solicitar a produção do que é denominado primeira produção do gênero, embora na apresentação da situação, os alunos façam uma produção escrita para uma avaliação diagnóstica inicial. 
Dolz, Noverraz e Schneuwly (2004) e outros pesquisadores, porém foram feitas alterações que vão desde a organização das etapas até os procedimentos adotados.

\section{OS PROJETOS DE LETRAMENTO NAS ESCOLAS: DA UNIVERSIDADE ÀS ESCOLAS}

Em termos de procedimentos metodológicos, primeiramente, apresentei o projeto de intervenção para os estagiários das minhas turmas de Estágio Curricular Supervisionado de Língua Portuguesa e Literaturas I, acadêmicos do $3^{\circ}$ ano de Letras, que puderam escolher realizá-lo ou não, uma vez que desenvolver atividades com projeto de intervenção é uma possibilidade no estágio, mas não obrigatoriedade. Em 2017, seis estagiários desenvolveram o projeto de intervenção e foram realizadas oficinas em duas escolas. Em 2018, sete estagiários realizaram oficinas em três escolas.

A seguir, apresento de maneira geral os encaminhamentos para o projeto de intervenção nas escolas por meio da pedagogia de letramento. Inicialmente, os estagiários estudaram os princípios epistemológicos de letramento e seus pressupostos teóricometodológicos, o trabalho com gêneros textuais e com a sequência didática de gêneros. Além disso, eles conheceram as orientações dos Parâmetros Curriculares Nacionais, as Diretrizes Curriculares do estado do Paraná para o ensino de Língua Portuguesa nos Anos Finais do Ensino Fundamental e as aprendizagens mínimas da área de Língua Portuguesa apresentadas na Base Nacional Comum Curricular.

Para tanto, os acadêmicos estagiários tinham um cronograma de estudos, além daquele que já fazia parte do plano de ensino de Estágio Curricular Supervisionado de Língua Portuguesa e Literaturas I. Embora a proposta não seja partir de conteúdos preestabelecidos, é importante considerar as orientações curriculares, assim como as aprendizagens mínimas para a Educação Básica, pois os acadêmicos estão em formação e, além de serem agentes de letramento, estão desenvolvendo saberes necessários à docência.

Posteriormente, confirmadas as escolas que tinham interesse nas oficinas, os estagiários as visitaram para providenciar a documentação obrigatória e então realizar as atividades, tais como levantamento do contexto educacional, carga horária de observação de aulas etc., etapa importante para o diagnóstico do trabalho (PIMENTA; LIMA, 2018).

Ao realizarem essas atividades obrigatórias os estagiários já deveriam ter uma 
postura sensível culturalmente (STREET, 2003) para identificar as necessidades e interesses da escola e dos alunos, o que também deveria ser feito no momento de apresentação. Tais observações foram fundamentais para o planejamento das oficinas, pois "no período de estágio, precisamos continuamente planejar e replanejar, para que possamos atingir os nossos objetivos, refletir sobre o concreto da realidade escolar e corrigir os desvios do processo" (PIMENTA; LIMA, 2018, s.p.).

Posteriormente, ocorreram as reflexões, o planejamento, a análise de materiais didáticos, a preparação de atividades para as oficinas e sua realização, bem como a socialização das produções textuais nas escolas. Por fim, ocorreram a reflexão, a avaliação do projeto de intervenção e a produção do relatório crítico. Durante todo o trabalho houve encontros de orientação e de sessões reflexivas (inseri as sessões reflexivas no processo a partir de 2018).

Em síntese, foram realizados os seguintes passos/procedimentos: apresentação da proposta para os estagiários; encontros periódicos de orientação e discussão do trabalho (no decorrer de todas as etapas; apresentação das propostas e definição das escolas para realização dos projetos; estudos teóricos dos pressupostos teórico-metodológicos pelos estagiários; regularização da documentação; levantamento do contexto educacional e observação do espaço escolar e das aulas; sessão reflexiva das observações; planejamento das oficinas (planos de aula para cada oficina e material didático); realização das oficinas (considerando replanejamento, se necessário); sessão reflexiva sobre as oficinas e avaliação do projeto desenvolvido na escola; elaboração de relatório crítico. Ao final, foram realizados momentos para socialização das produções dos alunos nas escolas. Além disso, alguns estagiários também divulgaram as experiências em eventos científicos do curso, com a publicação de resumos e apresentações de comunicações orais.

Em 2017, foram desenvolvidas oficinas em duas escolas, no entanto, o trabalho só foi concluído em uma ${ }^{8}$, já em 2018, as oficinas foram realizadas em três escolas.Todas as escolas eram da rede estadual de ensino de um município do Norte do Paraná. Tendo como base os interesses dos alunos para o desenvolvimento dos projetos de letramento nas oficinas, optamos por práticas sociais de leitura e escrita de diferentes domínios sociais da comunicação, tais como da cultura literária e ficcional, da documentação e memorização

\footnotetext{
${ }^{8}$ Houve desistência dos alunos que participaram das oficinas de uma das escolas.
} 
de ações humanas e da discussão de problemas sociais e controversos.

Em cada escola foi desenvolvida uma sequência de atividades por meio dos pressupostos de projetos de letramento e sobre uma prática de linguagem, totalizando oito oficinas, que eram semanais e com duração de 3 horas-aula, em contraturno, por 2 meses, totalizando 24 horas-aula ao final. Além disso, ocorreu mais uma etapa, que não considerei oficina, quando os acadêmicos estagiários voltaram às escolas para promover ou socializar a produção dos alunos, no caso das coletâneas organizadas. Para isso, foram organizados momentos para que outros alunos da escola também pudessem conhecer as produções. Em uma das escolas, familiares de alguns dos alunos foram acompanhar o momento de socialização das produções.

A seguir, apresento as produções resultantes dos projetos de letramento desenvolvidos nas oficinas. As duas primeiras produções, "Memórias Literárias" e "13 Contos Fantásticos", foram realizadas em uma mesma escola, uma em oficinas realizadas em 2017 e outra de oficinas que aconteceram em 2018. Por sua vez, a produção “Coletânea de poemas" é do trabalho resultante de outra oficina de $2018^{9}$. Cada estudante que participou das oficinas e produziu um texto para uma coletânea recebeu um exemplar no dia de realização da atividade de divulgação das produções na escola.

\footnotetext{
${ }^{9}$ A organização das produções, desde o trabalho de edição e de arte até os custos da produção, foi de responsabilidade dos acadêmicos estagiários e com minha colaboração. Agradeço aos acadêmicos estagiários por tornarem possível a concretização dos projetos de letramento nas escolas, bem como as práticas de linguagens com memórias, contos, poemas e resenhas. Seus nomes não serão citados para proteção de suas identidades devido a questões éticas.
} 
Figura 3: Produções finais

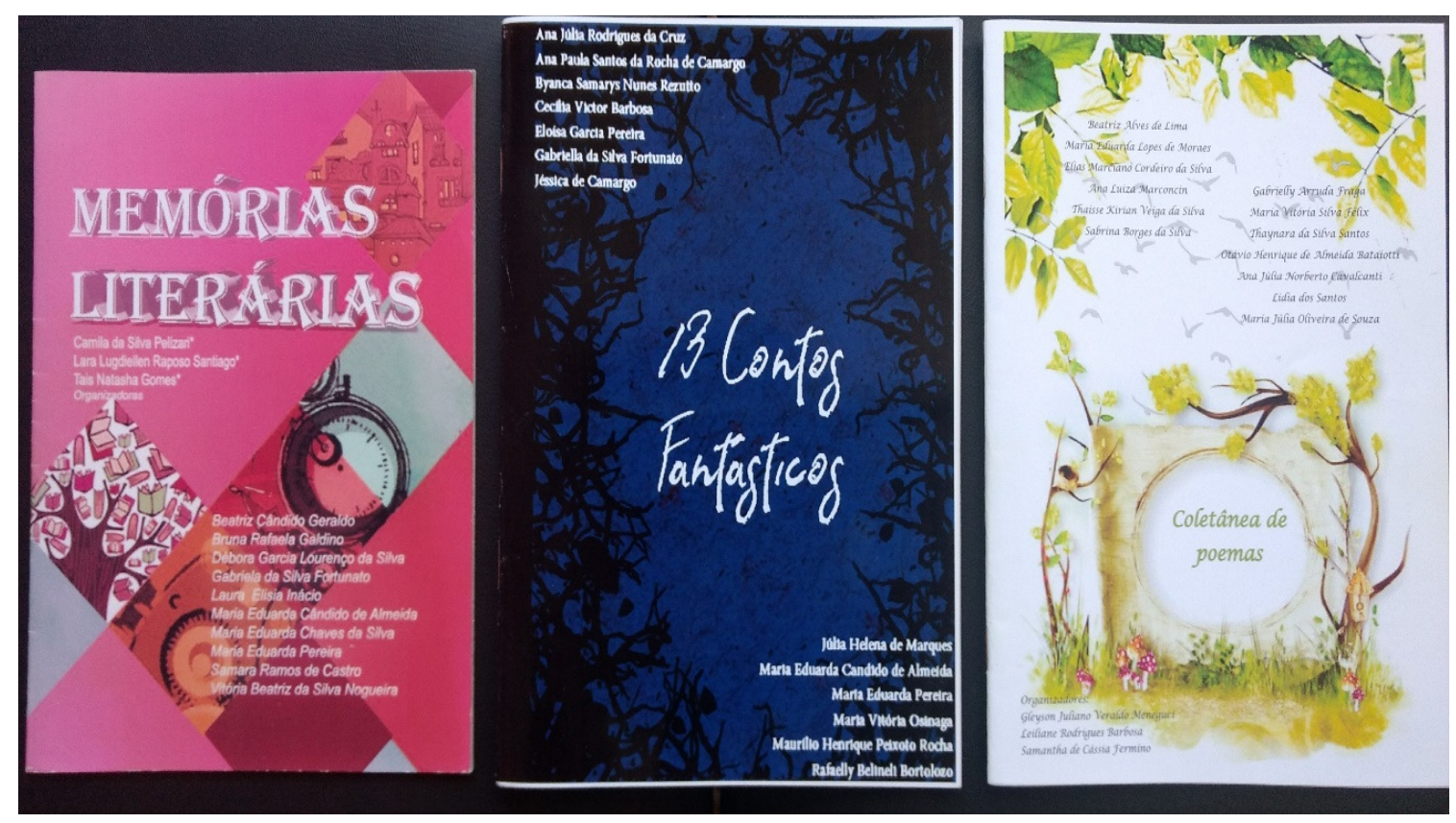

Fonte: A autora.

A primeira proposta de oficinas desenvolvidas pelo viés de projetos de letramento, considerando também o gênero textual como mediação das práticas sociais, foi realizada em 2017, no período de agosto a setembro. O trabalho foi desenvolvido por 3 estagiárias, com alunos dos Anos Finais do Ensino Fundamental, dos $6^{\circ}, 7^{\circ}, 8^{\circ}$ e $9^{\circ}$ anos. Inicialmente, 15 alunos participaram, mas apenas 10 permaneceram até a produção final dos textos.

A prática social que ancorou a sequência de atividades foi "Memórias literárias", domínio social de comunicação de cultura literária ficcional ou do campo de atuação artístico literário, com o objetivo de resgatar os saberes locais e vivências dos alunos e familiares. Houve o resgate das memórias infantis dos pais dos alunos, por meio de entrevistas e conversas. O objetivo final foi a organização de uma coletânea para que todos os textos produzidos pudessem circular na escola, na comunidade e na universidade.

Na sequência, apresento o sumário da coletânea "Memórias Literárias" e um relato de memórias, intitulado "Viagem no tempo". 
Figura 4: Páginas da produção "Memórias literárias"
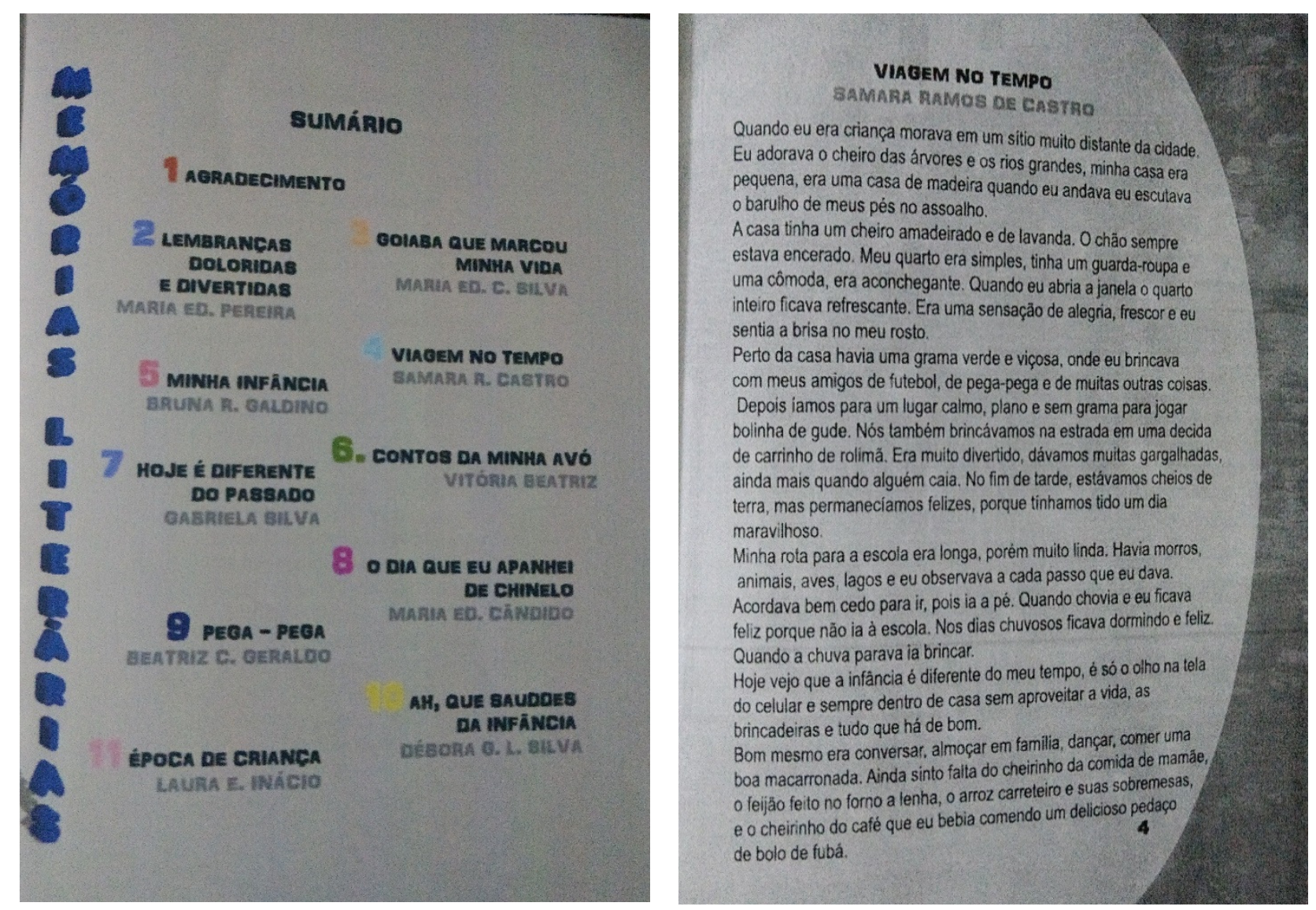

Fonte: A autora.

Nessa mesma escola, foi desenvolvido outro trabalho também para alunos do $6 .^{\circ}$ ao 9..$^{\circ}$ ano do Ensino Fundamental em 2018. As oficinas foram ministradas por 3 estagiários, no período de agosto a setembro de 2018, com a carga horária semanal de 3 horas-aula, totalizando 24 horas-aula, e contaram com participação inicial de 16 alunos (dos quais 13 concluíram).

A prática social de escrita "Contos Fantásticos" também foi do domínio social de comunicação de cultura literária ficcional ou do campo de atuação artístico literário. $\mathrm{O}$ objetivo era organizar uma coletânea de contos para circular na escola, na comunidade e na universidade.

A seguir, apresento parte do sumário da coletânea organizada e o início de um dos contos, intitulado "A garota da lacuna” (o conto na íntegra está em anexo). 
Figura 5: Páginas da produção "Contos fantásticos"
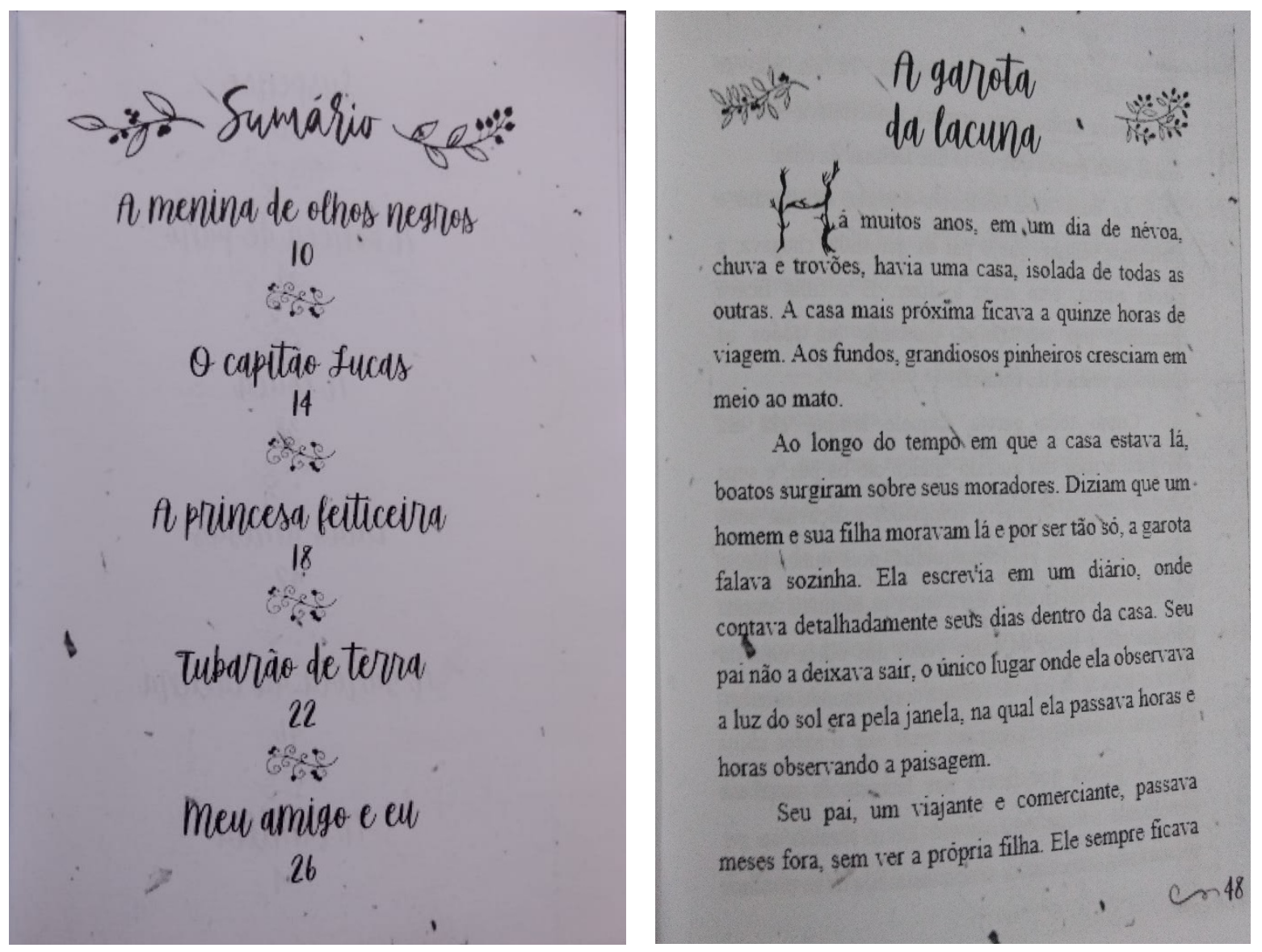

Fonte: A autora.

Em outra escola, também com a participação de 3 estagiários, entre agosto e novembro de 2018, trabalhamos com outro gênero voltado para uma prática social de escrita, o "Poemas", do domínio de comunicação de cultura literária e ficcional ou do campo artístico literário, também para a organização de uma coletânea com os textos a fim de circularem na escola, na comunidade e na universidade. Participaram das oficinas semanais inicialmente 17 alunos dos $8^{\circ}$ e $9^{\circ}$ anos do Ensino Fundamental, mas apenas 13 concluíram o projeto.

Inicialmente, havia no grupo de alunos que frequentava a oficina uma aluna cega que fazia as leituras e escrevia no sistema Braille. A intenção era organizar uma coletânea com os poemas produzidos pelos alunos também com versões em Braille. A aluna chegou a produzir a primeira versão do seu poema, mas por questões pessoais parou de frequentar as oficinas. Com a sua desistência, os estagiários não levaram a diante o propósito da 
organização de uma coletânea com os poemas em Braille.

A seguir, apresento dois poemas da coletânea.

Figura 6: Páginas da produção "Poemas"
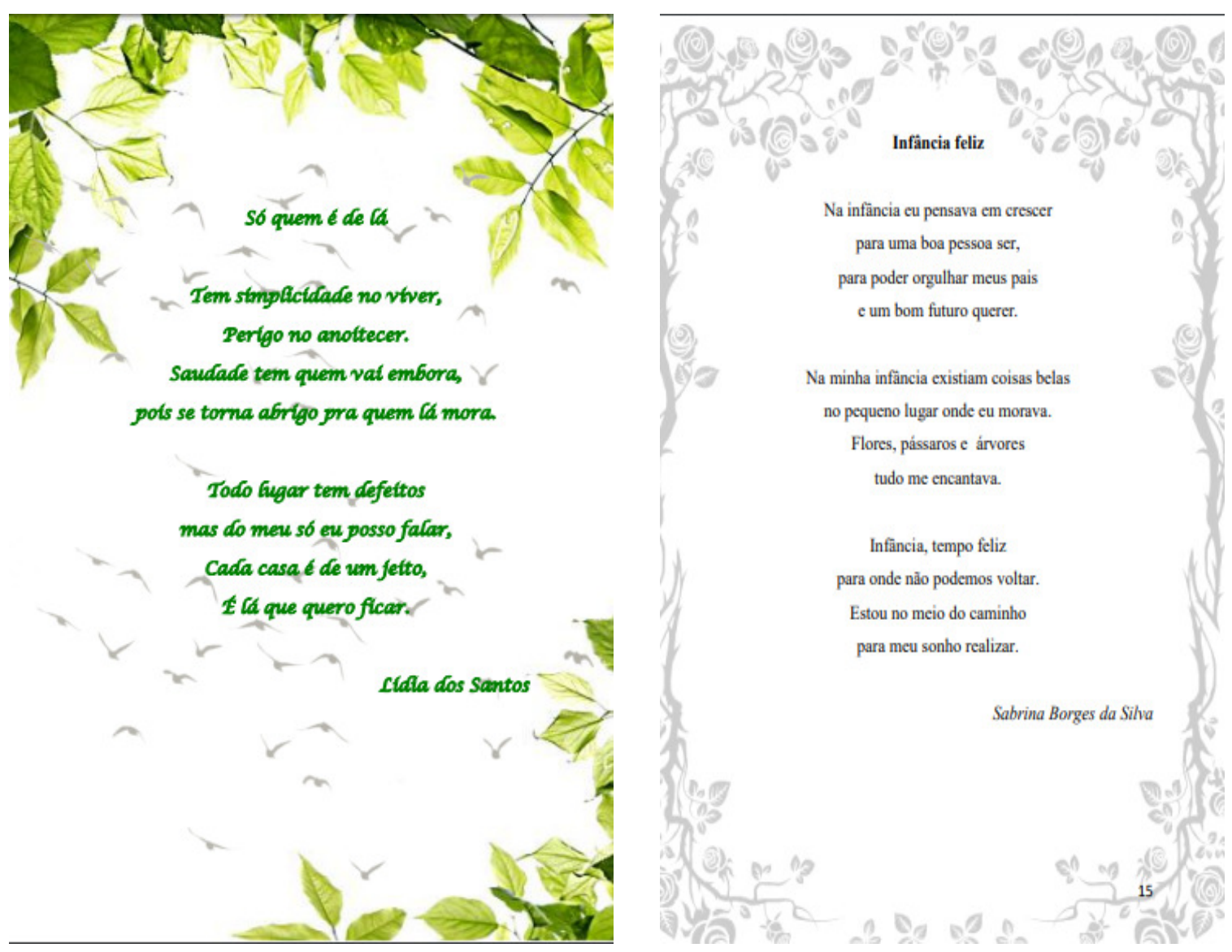

Fonte: A autora.

Também em 2018, entre agosto a outubro, na terceira escola, uma estagiária realizou oficinas com alunos dos $8^{\circ}$ e $9^{\circ}$ anos do Ensino Fundamental, com a participação inicial de 19 alunos, mas apenas 5 finalizaram o projeto. A carga horária semanal foi de 3 horas aula, totalizando 21 horas aula.

A prática que norteou o desenvolvimento do projeto de letramento nessa escola foi a do domínio social de discussão de problemas controversos, para sustentação, refutação e negociação de tomadas de posição, especificamente da esfera jornalística ou do campo jornalístico e midiático. Assim, definiu-se a "resenha crítica de filme" para publicação em uma revista da cidade, que circulava mensalmente nas versões impressa e online. No 
entanto, as publicações não ocorreram devido a um problema da revista.

A seguir apresento uma resenha sobre o filme "Divertida Mente".

Figura 7: Produção "resenha de filme"

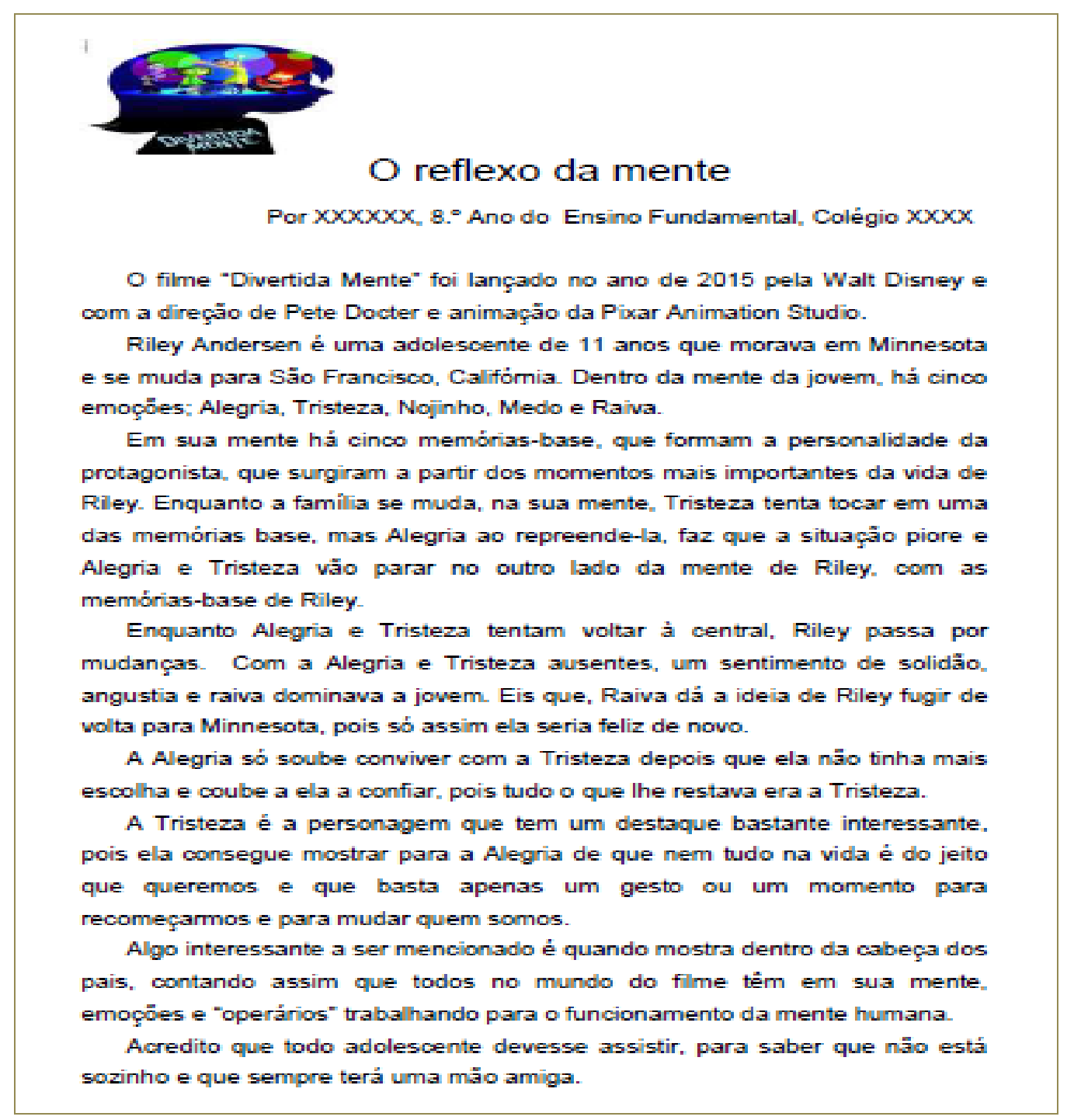

Fonte: A autora.

Com base no percurso do projeto de intervenção com a realização de oficinas nas três escolas, por meio de projetos de letramentos voltados para práticas de linguagem distintas (dois projetos em uma mesma escola, um em 2017, outro em 2018), pude perceber resultados melhores descritos a seguir.

Verificou-se que, de fato, as oficinas em contraturno constituíram-se como espaços 
e tempos diferenciados para a aprendizagem, o que foi reconhecido pela direção das escolas e pelos acadêmicos estagiários de Letras envolvidos no processo.

O projeto de letramento na escola pública possibilitou os alunos a oportunidade de desenvolver suas capacidades de leitura, interpretação e produção de textos e pelos próprios adolescentes, de acordo com usas necessidades sociais específicas [...] $\mathrm{O}$ fato do projeto ocorrer em horário contraturno é um ponto positivo, se analisado pela perspectiva de que os alunos possuem um tempo período extra para se dedicarem e aprimorarem os conteúdos [...]. (Excerto de texto produzido por uma acadêmica do $3^{\circ}$ ano do curso de Letras). ${ }^{10}$

Esse resultado também pode ser verificado de modo explícito na visão dos adolescentes participantes "Bom, essas atividades sempre chamam muito atenção, e eu gosto muito de aprender coisas novas" (Resposta de aluna do $8^{\circ}$ ano de uma das escolas campo de estágio).

Dessa forma, o trabalho com leitura e escrita voltado para práticas de linguagem, que realmente iriam circular socialmente com uma finalidade e interlocutores reais, possibilitou que os alunos adolescentes realmente se engajassem durante as oficinas, mas ao mesmo tempo trouxeram à tona alguns conflitos desses adolescentes como sujeitos sócio-historicamente legitimados a produzirem textos para circularem e serem lidos para além da sala de aula com vistas a verificação de aprendizagem e enquanto estudantes capazes de fazerem, de dizerem, de narrarem, de se expressarem e de se posicionarem por meio da escrita.

Nos primeiros encontros voltados para produção escrita ao mesmo tempo que os alunos queriam produzir, não se consideravam estudantes capazes ou indivíduos que de fato tinham coisas importantes para dizer. Então, tivemos que pensar em estratégias para legitimá-los como aprendizes capazes. Desse modo, além de espaços e tempos para a aprendizagem, o trabalho possibilitou reconhecimento e legitimação de suas identidades enquanto estudantes e de seus papéis sociais na comunidade.

Por fim, o trabalho possibilitou aos estagiários uma experiência teóricometodológica e didática para atuar nos Anos Finais do Ensino Fundamental, bem como a

\footnotetext{
${ }^{10}$ Ao final das oficinas realizadas em 2018, os alunos das escolas responderam a um questionário e os acadêmicos estagiários produziram um texto de cunho crítico-reflexivo sobre as atividades realizadas no projeto de intervenção e o desenvolvimento das oficinas pelo viés dos projetos de letramento.
} 
oportunidade de articularem a teoria e a prática, com uma preocupação com a realidade escolar. "As práticas desenvolvidas ao longo do projeto colaboraram para o desenvolvimento dos conteúdos que estudamos e também para que pudéssemos contribuir com a aprendizagem dos alunos da escola" (Excerto de texto de uma acadêmica do $3^{\circ}$ ano de Letras).

Em suma, foi possível perceber que os acadêmicos estagiários tomaram para si as responsabilidades e efeitos do trabalho, isso porque "à medida que se sentem coautoras e não apenas executoras, as pessoas estão assumindo melhor o projeto e suas consequências" (PIMENTA; LIMA, 2018, s.p), o que contribuiu para a formação docente dos acadêmicos.

\section{CONSIDERAÇÕES FINAIS}

Neste texto, relatei minha experiência como orientadora de Estágio Curricular Supervisionado de Língua Portuguesa e Literaturas I, com um projeto de intervenção no estágio supervisionado que objetivou que acadêmicos estagiários desenvolvessem oficinas para alunos dos Anos Finais do Ensino Fundamental, com base na pedagogia de projetos de letramento e nas discussões sobre gêneros textuais e sequência didática.

É possível afirmar que a realização de parte do estágio por meio de projetos de intervenção contribuiu tanto para a escola, representada pelos alunos, quanto para os acadêmicos estagiários. As oficinas desenvolvidas pelos acadêmicos do $3^{\circ}$ ano de Letras Português/Inglês colaboraram para a ampliação de espaços e tempos para a aprendizagem dos alunos nas três escolas, bem como para a ampliação de suas práticas sociais de leitura e escrita. Isso ocorreu porque, por meio de projetos de letramento, foram desenvolvidas práticas comunicativas mais contextualizadas, que buscavam a valorização de interesses, de saberes locais e a legitimação de identidades sociais, sobretudo dos alunos capazes de atuarem, expressarem-se e posicionarem-se por meio de leitura e escrita, ao produzirem poemas, relatos de memórias, contos e resenhas.

Mesmo que os alunos não sejam de fato poetas, contistas ou resenhistas e que, ao produzirem seus textos em situação escolar, estavam produzindo gêneros deslocados de suas práticas sociais de referência, mesmo que estas fossem consideradas ponto de partida e também ponto de chegada. Saliento que, conforme Barros, Mafra e Storto (2017), ainda 
que o gênero de texto esteja deslocado da sua prática social de referência, pois mesmo o aluno assumindo um papel de resenhista, por exemplo, não é um, “[...] a finalidade é de que o aprendiz se coloque na posição de produtor [...]. Que ele aprenda agir discursivamente por meio de textos representativos de diferentes esferas sociais [...]" (BARROS; MAFRA; STORTO, 2017, p. 155).

Nesse sentido, de acordo com Schneuwly e Dolz (2004, p. 81), "[t]rata-se de colocar os alunos em situação de comunicação que sejam as mais próximas possíveis de verdadeiras situações de comunicação, que tenham um sentido para eles [...]". Ou, retomando Kleiman (2000), trata-se de se desenvolver uma sequência de atividades a partir de um interesse real dos alunos, da leitura e da escrita de textos que circulem na sociedade e sejam, de fato, lidos.

O desdobramento da experiência relatada neste texto também auxiliou na formação dos acadêmicos de Letras para o exercício da docência, principalmente nos Anos Finais do Ensino Fundamental, com uma articulação entre teoria e prática, pautada numa reflexão contínua e com posturas mais autônomas no planejamento e na realização das oficinas para projetos de letramento, assim corroborando o que destacam Pimenta e Lima (2018, s.p): “a realização do estágio em forma de projetos desenvolve uma atitude de autonomia e de criatividade dos estagiários, uma vez que possibilita a descoberta de espaços de intervenção significativa para sua formação e para as escolas.”.

Nessa perspectiva, realizar Estágio Curricular Supervisionado com o desenvolvimento de projetos de intervenção

[...] supõe, pois, o compromisso de realizar projetos significativos para uma escola de melhor qualidade, voltada à inclusão social e em constante diálogo entre os participantes. É somente acreditando que as pessoas, juntas, têm a capacidade de transformar a realidade que o projeto pode deixar de ser um instrumento burocrático para ser um instrumento de ensino [...]. (PIMENTA; LIMA, 2018, s.p).

Desse modo, não se trata apenas de um instrumento para a formação docente, mas de um ensino que pode ser significativo, mesmo que minimamente, como no caso do trabalho relatado neste texto, para transformar a realidade dos alunos. Isso vai ao encontro do que reforçam Borges da Silva e Ferreira da Silva (2016, p. 224), no sentido de que a complexidade inerente ao processo de formação “[...] para além dos conteúdos, exige uma 


\section{REVISTA $\mathbf{X}$}

prática de reflexão, de autoconhecimentos e da compreensão da dimensão política inerente a todo fazer pedagógico (confira Freire 1989 e 2001)".

Certamente, experiências como esta relatada neste texto são muito pequenas em termos de abrangência e no número de envolvidos, considerando as várias demandas para a formação docente e as necessidades da realidade escolar. Porém, com base neste percurso, vejo como profícuo o desenvolvimento de projetos no Estágio Curricular Supervisionado de Língua Portuguesa e Literaturas, em especial também quando realizados no campo de estágio para além do componente curricular de língua portuguesa e das classes regulares, em outros espaços e momentos tanto de aprendizagem na escola quanto de trajetória na docência.

\section{REFERÊNCIAS}

ALMEIDA, M. I.; PIMENTA, S. G. Estágios supervisionados na formação docente. São Paulo: Cortez, 2014.

BARBOSA, L. R.; MENEGUCI, G. J. V.; FERMINO, S. C. (Org.). Coletânea de poemas. Cornélio Procópio/PR, 2018.

BARROS, E. M. D. de. Gestos de ensinar e de aprender gêneros textuais: a sequência didática como instrumento de mediação. 2012. 358f. Tese (Doutorado em Estudos da Linguagem) - Universidade Estadual de Londrina, Londrina/PR, 2012.

; BARDINI, V. S. A construção de sequências didáticas para o ensino da língua: uma proposta didática mediada pelo gênero "crônica humorística". Entretextos, Londrina, v. 12, n. 2, p. 80-112, jul./dez., 2012.

; STORTO, L. J (Org.). Gêneros do jornal e ensino: práticas de letramento na contemporaneidade. Campinas, SP: Pontes Editores, 2017.

; MAFRA, G. M.; STORTO, L. J. O Gênero "Resenha de Filmes": De objeto social de referência a objeto didático. In: BARROS, E. M. D; STORTO, L. J. (Org.) Gêneros do jornal e ensino: práticas de letramentos na contemporaneidade - Campinas, SP: Pontes Editores, 2017, p. 151-181.

; STRIQUER, M.; STORTO, L. J. (Org.) Propostas didáticas para o ensino da língua portuguesa. Campinas, SP: Pontes Editores, 2018.

BORGES DA SILVA, S. B. Contornos dos letramentos. Cad. CEDES, Campinas, v. 33, n. 90, p. 279-287, 2013. Disponível em: <http://dx.doi.org/10.1590/S010132622013000200007> . Acesso em: 29 abr. 2019. 
; FERREIRA DA SILVA, L. Etnografia e autoetnografia na formação de professores. In: KLEIMAN, A.; ASSIS, J. A. (Org.). Significados e Ressignificações do Letramento.1.ed. Campinas: Mercado de Letras, 2016, p. 223-252.

BRANDILEONE, A. N. F. Práticas de leitura e produção textual: educação básica e formação inicial em foco. Projeto de extensão. Universidade Estadual do Norte do Paraná, Cornélio Procópio, 2018 (não publicado).

BRASIL. Ministério da Educação. Secretaria de Educação Fundamental. Parâmetros curriculares nacionais: terceiro e quarto ciclos do ensino fundamental: Língua Portuguesa. Brasília: MEC, 1998.

Ministério da Educação. Secretaria de Educação Básica. Base Nacional Comum Curricular: Ensino Fundamental.Brasília: MEC, 2017.

CORDEIRO, G. S.; BARROS, E. M. D. de.; GONÇALVES, A. V. (Org.). Apresentação. In: CORDEIRO, G. S.; BARROS, E. M. D. de.; GONÇALVES, A. V. (Org.). Letramentos, objetos e instrumentos de ensino: gêneros textuais, sequências e gestos didáticos. Campinas, SP: Pontes Editores, 2017, p. 15-21.

DOLZ, J; NOVERRAZ, M.; SCHNEUWLY, B. Sequências didáticas para o oral e a escrita: apresentação de um procedimento. In: SCHNEUWLY, B.; DOLZ, J. e colaboradores. Gêneros orais e escritos na escola. Campinas-SP: Mercado das Letras, 2004, p. 95-128.

DOLZ, J; SCHNEUWLY, B. Gêneros e progressão em expressão oral e escrita: elementos para reflexões sobre uma experiência Suíça (Francófona). In: SCHNEUWLY, B.; DOLZ, J. e colaboradores. Gêneros orais e escritos na escola. Campinas-SP: Mercado das Letras, 2004, p. 41-70.

FORTUNATO, G. da S. A garota da lacuna. In: VARESCHI; G. M.; FERREIRA, I. T.; FÉLIX, L. D. B. (Org.). 13 Contos Fantásticos. Cornélio Procópio/PR, 2018, p. 46-52.

GUIMARÃES, A.; KERSCH, D. F. E então... caminhos da construção de projetos didáticos de gênero - da comunidade de indagação ao desenvolvimento de professoras(es) e das pesquisadoras. In: GUIMARÃES, A.; CARNIN, A.; KERSCH, D. F. Reflexões sobre projetos didáticos de gêneros. São Paulo: Mercado de Letras, 2015, p. 7-28.

KLEIMAN, A. B. Os significados do letramento.Uma nova perspectiva sobre a prática social da escrita. Campinas: Mercado de Letras, 1995.

O processo de aculturação pela escrita: ensino de forma ou aprendizagem da função? In: KLEIMAN, A. B.; SIGNORINI, I. (Org.). O ensino e a formação do professor: alfabetização de jovens e adultos. Porto Alegre: Artes Médicas do Sul, 2000, p.223-243. 
. Letramento e suas implicações para o ensino de língua materna. Signo. Santa Cruz do Sul, v. 32, n. 53, p. 1-125, 2007.

. Preciso "ensinar letramento"? Não basta ensinar a ler e a escrever. Linguagem e letramento em foco. IEL/Unicamp, 2010.

LAVE, J.; WENGER, E. Situated learning: Legitimate peripheral participation. New York: Cambridge University Press, 1991.

MANUAL DE ESTÁGIO SUPERVISIONADO OBRIGATÓRIO DO CURSO DE LETRAS PORTUGUÊS/INGLÊS. Colegiado de Letras. Universidade Estadual do Norte do Paraná, Cornélio Procópio, 2018.

OLIVEIRA, M. Projetos: uma prática de letramento no cotidiano do professor de língua materna. In: KLEIMAN, A. B.; OLIVEIRA, M. S. (Org.). Letramento múltiplos: agentes, práticas, representações. Natal/ RN: EDUFRN, 2008, p. 93-118.

2010.

Gêneros textuais e letramento. RBLA, Belo Horizonte, v. 10, n. 2, p. 325-345,

PARANÁ. Secretaria de Estado da Educação. Diretrizes Curriculares de Língua Portuguesa para os Anos Finais do Ensino Fundamental e Ensino Médio: Língua Portuguesa. Curitiba: SEED, 2008.

PELIZARI, C. da S.; SANTIAGO, L. L. R.; GOMES, T. N. (Org.). Memórias Literárias. Cornélio Procópio/PR, 2017.

PIMENTA, S. G.; LIMA, M. DO S. Estágio e docência [livro eletrônico]. 1. ed. em ebook baseada na 8. ed. impressa. São Paulo: Cortez Editora. Edição do Kindle, 2018.

PROJETO PEDAGÓGICO DO CURSO DE LETRAS PORTUGUÊS/INGLÊS. Colegiado de Letras. Universidade Estadual do Norte do Paraná, Cornélio Procópio, 2012.

ROJO, R. Letramento e diversidade textual. In: CARVALHO, M. A.; MENDONÇA, R. H. (Org.). Práticas de leitura e escrita. Brasília: Ministério da Educação, 2006, p. 24-29.

SOARES, M. Práticas de letramento e implicações para a pesquisa e para políticas de alfabetização e letramento. In: MARILDES, M; CARVALHO, G. T. (Orgs). Cultura escrita e letramento. Belo Horizonte: Editora UFMG, 2010, p. 68-100.

SOUZA, A. G.; OLIVEIRA, M. Os projetos de letramento como instrumentos de ressignificação do tempo, do espaço e dos materiais escolares. GELNE, v. 19, n. especial, p. 139-154, 2017.

STREET, B. Abordagens Alternativas ao Letramento e Desenvolvimento. Palestra apresentada durante a Teleconferência Unesco Brasil sobre "Letramento e Diversidade". King's College, Londres, 2003. 
Letramentos sociais: abordagens críticas do letramento no desenvolvimento, na etnografia e na educação. Tradução Marcos Bagno. São Paulo: Parábola Editorial, 2014.

STRIQUER, M.; OLIVEIRA, S. Uma proposta de ensino organizada a partir do gênero textual "artigo de opinião". In: BARROS, E. M.; STORTO, L. J. Gêneros do jornal e ensino: práticas de letramento na contemporaneidade. Campinas, SP: Pontes Editores, 2017, p. 119-150.

VALENTE, T. A. Leitura e produção textual:atuação comunitária. Projeto de extensão. Universidade Estadual do Norte do Paraná, Cornélio Procópio, 2017 (não publicado).

VARESCHI; G. M.; FERREIRA, I. T.; FÉLIX, L. D. B. (Org.) 13 Contos Fantásticos. Cornélio Procópio/PR, 2018.

\author{
ANEXO \\ CONTO "A GAROTA DA LACUNA”
}




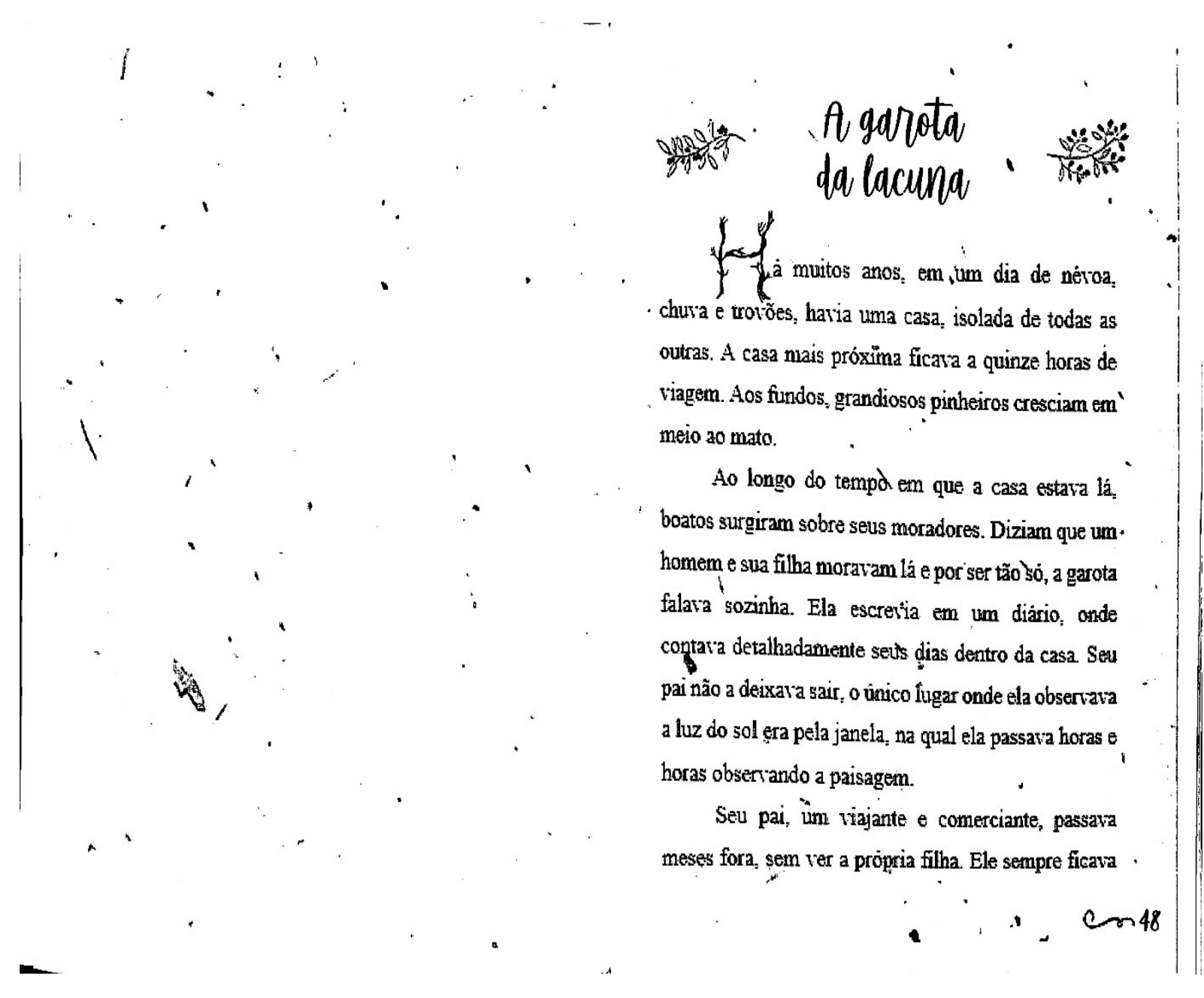



angustiado aó pensar na menina Jà ela não se preocupara muito, pois sempre mencionara, em seu diârio, uma garota que vivia nas lacunas da casa.

As duas eram melhores amigas, brincavam e riam, mas sempre que o pai da garotinha chegara, a garota sumia, sem nada a dizer. E a filha ficasa chamando por sua amiga, passando en todos os còmodos, menos na raranda.

Como toda garota daquele tempo, ela era obrigada a usar um vestido branco ate os pés, e seus cabelos longos, nëgros e compridos realçaram seus

$\checkmark$ olhos azuis e sua pele branquinha, pois nunca haria tomado sol. Havia uma regra entre as meninas: nunca podiam othar mais de cinço vezes nos olhos uma da

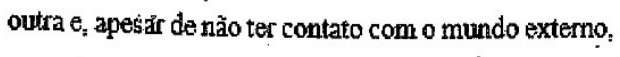
a menina sabia dessas regras.

- A garota que ficava nas lacunas da casa" era semellhante a uma menina que haria sumido ao ser sequestrada, nunca mais sendo vista. Ela tinha os olhos $49 m$
$\$$

amarelos, cabelos escuros e longos, pele clara e usara um restido branco:

Certo dia, enquanto as garotas brincaram e consersaram, a menina da lacuna disse:

- Venha brincar comigo para sempre, onde eu moro tenho de tudo.

Mas a moradora da casa'sempre respondia:

- Não, tenho saudades do meu pai, porque o rejo poucas rezes.

A pequent moradora foi crescendo, com mais curiosidade de conhecer o mundo lá fora, mas seu pai a proibia de sair. Um dia, o homem saiu de casa para viajar e sua filha, como sempre, ficou. A curiosidade de $e^{\prime}$ conhecer o mundo exterior tomava conta dela, mas nâo poderia sair, enitào, ela chamou a amiga para pedir. ajuda sobre o que fazer em relaçăo a isso, e a garota disse para a outra ir.

Antes de ir, ela chamou a amiga misteriosa, mas ela disse não poder sair, pois estava presa à casà. A 


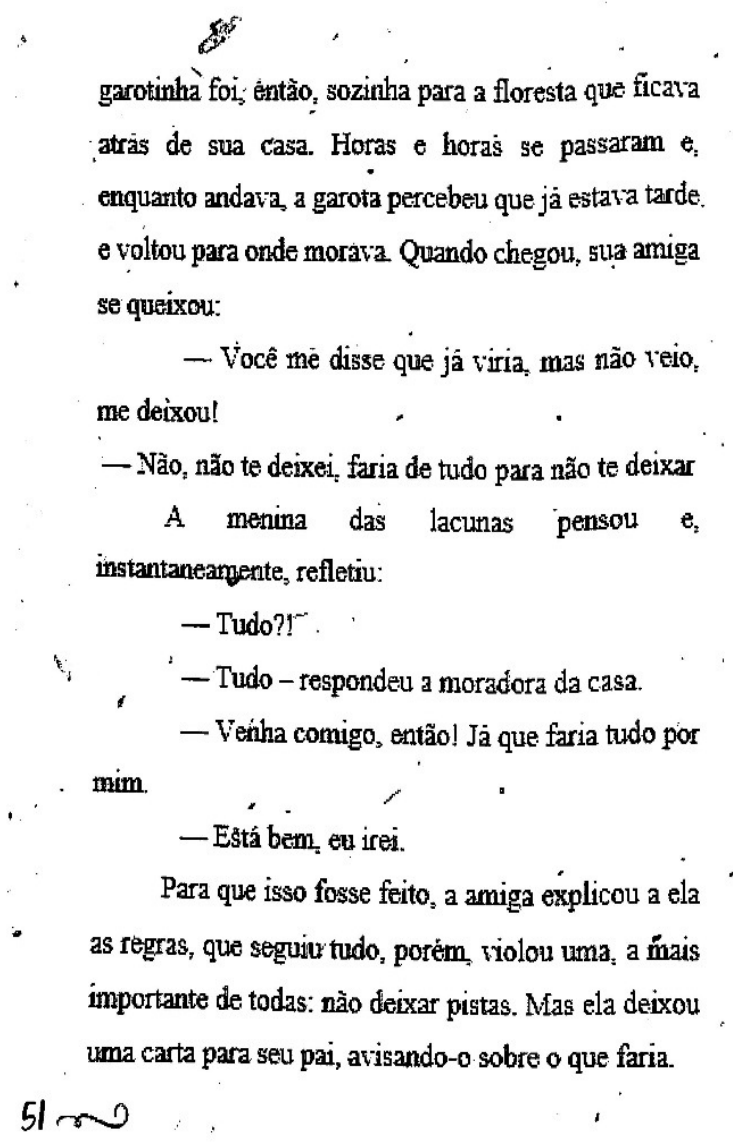

5

Meses se passaram, até que seu pai retornou à casa $e_{\text {, a }}$ entrar, éncontrou uma pequena carta no hall da casa. Depois de lê-la, foi correndo, desesperado, ao quarto $\mathrm{da}$ filha, onde se deparou com o corpo dela em meio às cortinas.

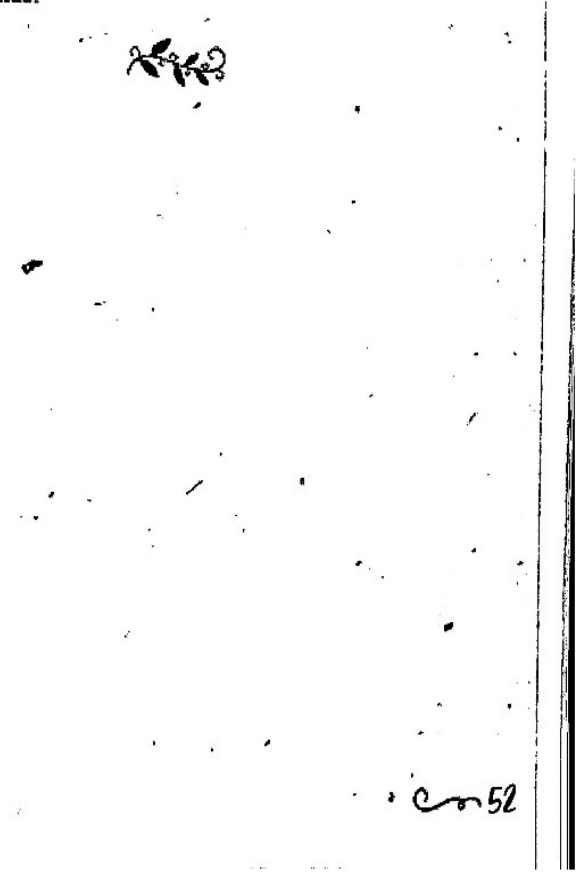

Recebido em: 19 mai. 2020.

Aceito em: 31 ago. 2020. 